\title{
Constraints Faced by the Respondents in Adopting Inter-Cropping Practices of Black Pepper and Betel Vine in Arecanut Plantation in Jirang Block of Ri-Bhoi District, Meghalaya, India
}

\author{
Dasiewdorshisha Sancley* and Syed H. Mazhar
}

Department of Agricultural Extension \& Communication, SHUATS, Prayagraj-211007, India

*Corresponding author

\section{Ke y w o r ds \\ Areca nut, Black pepper, Betel vine, constraints, Inter- cropping, Ri-Bhoi \\ Article Info \\ Accepted: 04 August 2020 Available Online: 10 September 2020}

\begin{abstract}
A B S T R A C T
Constraints are something that imposes a limit or restriction or that prevents something from occurring. These constraints affect the farming practices of the farmers in Jirang block and lower down their income level in many sphere. Therefore, the purposed of this research was to find out the constraints faced by the respondents in adopting intercropping practices of black pepper and betel vine in areca-nut plantation in Jirang block of Ri-Bhoi district, Meghalaya. Jirang Block which is in Ri-Bhoi district of Meghalaya was selected purposively keeping into the fact that less research has been conducted in the recent past and due to the maximum number of the farmers are cultivating areca nut and those of which practice inter-cropping within this block. Since time immemorial, areca nut has been grown in Meghalaya as an important commercial crop. Inter-cropping of crops like black pepper and betel vine has also been started by the farmers for many years as a source of income generation but the management practices was not up to the mark due to many constraints in their farming practices. The research design that was used for this study was an ex-post facto research design. The sample study was selected through multistage sampling method in the selected study area of the respondents. Number of respondents was selected using a simple random method by using computer aided random selection based on the criteria of farmers who were practicing areca nut plantation plus inter-cropping. A survey of 310 adopters was done by collecting the primary data using an interview schedule. Ranking method system was used as a statistical measurement for interpretation of the data and results. Independent variables included in this study were gender, age, marital status, educational level, and type of house, family size, family type, social category, and annual income, information seeking behaviour, participation in extension activities, social participation, innovativeness, scientific orientation, economic motivation and risk orientation which were used to analysed the socio-economic characteristics of the respondents.
\end{abstract}

\section{Introduction}

Areca nut is the major source of livelihood for small and marginal farmers in Ri-Bhoi
District of Meghalaya. Most of the farmers depend on the income from areca nut due to its ability to thrive well in this area. Multiple cropping has been practiced for centuries by 
small-scale farmers to reduce the risk of crop failure, attain higher yields, and to improve soil fertility (Litsinger and Moody, 1976).

The main objectives of this study to find out the constraints faced by the respondents in adopting inter-cropping practices of black pepper and betel vine in areca-nut plantation in Jirang block of Ri-Bhoi district, Meghalaya".

\section{Review of literatures}

Hong et al., (2019) found out that the share of land under intercropping in the optimal land use is shrinking with the growing scarcity of water, with a declining maize price, and with increasing off-farm employment in combination with higher labor wages. Dai et al., (2017) concluded that there was a significant decline in crop yields, increased demand for scarce water resources, increased demand for labor due to the labor-intensive nature of intercropping, and insecure land tenure. Haneef et al., (2019) concluded that majority of the respondents (89.00 percent) expressed initial low price for the organic produce which is of the same case that happens for inter-cropping of black pepper and betel vine.

\section{Materials and Methods}

The present study was conducted in purposively selected district Ri-Bhoi of Meghalaya where practicing of areca nut plantation prevails in large numbers. Further, out of the three blocks in Ri-Bhoi district, Jirang block was selected purposively thereafter 12 villages and 310 respondents was selected through simple random sampling. An Ex-Post facto research design was used for this study. With the help of an ex-post facto research, the researcher tries to analyse the cause and effect phenomena of an event, action or behaviour or controlled and uncontrolled group which is appropriate for studying the constraints in inter-cropping among the areca nut growers in $\mathrm{Ri}$-Bhoi district, since this event had already occurred.

The independent variables selected for this study were age, gender, marital status, educational status, type of house, family size, family type, social categories, occupation ,size of land holdings, annual income, information seeking behaviour, participation in extension activities, social participation, innovativeness, economic motivation, scientific orientation and risk orientation. The data was gathered using pre-tested and semistructured interview schedule. Collected data were analysed with the suitable statistical tools and the results was therefore interpreted subsequently.

\section{Results and Discussion}

\section{Over-all socio-economic characteristics level of the adopters and the non-adopters}

From table 1, it is revealed that the majority of the adopters accounted for 47.42 per cent are having high socio-economic characteristics, followed by 40.33 per cent of medium level and 12.25 per cent that of low level characteristics.

he findings were also corroborated those of Jaganathan and Nagaraja (2015) and Kumaran et al., (2018).

The table 2 shows the following results:

\section{Input constraints}

The input constraints faced by the adopters in inter-cropping practices depicted from the table 2 based on the ranking from the major to the minor includes the non availability of inputs supplier ( ${ }^{\text {st }}$ Rank), non-availability of good quality inputs (II ${ }^{\text {nd }}$ Rank), nonavailability of good planting materials (III ${ }^{\text {rd }}$ 
Rank), unavailability of labour (IV ${ }^{\text {th }}$ Rank) and the shortage of water ( $\mathrm{V}^{\text {th }}$ Rank).

\section{Technological constraints}

The technological constraints faced by the adopters in inter-cropping practices depicted from the table 2 based on the ranking from the major to the minor includes the lack of government support for inter-cropping system ( ${ }^{\text {st }}$ Rank), lack of knowledge about pest and disease (II ${ }^{\text {nd }}$ Rank), lack of training infrastructure (III ${ }^{\text {rd }}$ Rank), lack of knowledge on inter-cropping system ( $\mathrm{IV}^{\text {th }}$ Rank) and lack of resistant varieties against pest and diseases ( $\mathrm{V}^{\text {th }}$ Rank).

\section{Economic constraints}

The economic constraints faced by the adopters in inter-cropping practices depicted from the table 2 based on the ranking from the major to the minor includes the non availability of subsidies( $\mathrm{I}^{\text {st }}$ Rank), unavailability of regular market(II ${ }^{\text {nd }}$ Rank), they did not get minimum price as compare top areca nut (III ${ }^{\text {rd }}$ Rank), exploitation by middle man (IV ${ }^{\text {th }}$ Rank), price fluctuation of farm produce ( $\mathrm{V}^{\text {th }}$ Rank), low yield of the inter-crops ( $\mathrm{VI}^{\text {th }}$ Rank) and increased cost of cultivation (VII ${ }^{\text {th }}$ Rank)

\section{Biophysical constraints}

The biophysical constraints faced by the adopters in inter-cropping practices depicted from the table 2 based on the ranking from the major to the minor includes the nonavailability of space for planting ( ${ }^{\text {st }}$ Rank), poor quality of the soil (II ${ }^{\text {nd }}$ Rank), incidence of pests and diseases (III ${ }^{\text {rd }}$ Rank), due to high slope of the land (IV ${ }^{\text {th }}$ Rank) and sometimes the attack by domestic animals at the younger stage of the crops ( $\left.\mathrm{V}^{\text {th }} \mathrm{Rank}\right)$.

\section{Psychological constraints}

The psychological constraints faced by the adopters in inter-cropping practices depicted from the table 2 based on the ranking from the major to the minor are the difficulty for intercultural operations/harvesting( $\mathrm{I}^{\text {st }}$ Rank $)$, reduction in yield of main crop by component crops(II ${ }^{\text {nd }}$ Rank) and due to time consuming(III ${ }^{\text {rd }}$ Rank).

In input constraints the farmers faced a major restriction in inter-cropping due to the unavailability of supplier within the locality. The lack of infrastructure and support by the government make the farmers more difficult for the success of their crop production because the farmers are mostly having a medium level income to poor level of income.

Table.1 Over-all socio-economic characteristics level of the respondents

\begin{tabular}{|l|l|c|c|c|c|}
\hline \multirow{2}{*}{ Sr. No. } & Cat egory & \multicolumn{2}{|c|}{ Adopters } & \multicolumn{2}{c|}{ Non-Adopters } \\
\cline { 3 - 5 } & & Frequency & Percentage & Frequency & Percentage \\
\hline 1. & Low (18 to 45 Score) & 38 & 12.25 & 93 & 30.00 \\
\hline 2. & Medium (46 to 73 Score) & 125 & 40.33 & 152 & 49.04 \\
\hline 3. & High (74 to 103 Score) & 147 & 47.42 & 65 & 20.96 \\
\hline & Total & $\mathbf{3 1 0}$ & $\mathbf{1 0 0 . 0 0}$ & $\mathbf{3 1 0}$ & $\mathbf{1 0 0 . 0 0}$ \\
\hline
\end{tabular}


Table. 2 Constraints faced by the respondents in adopting inter-cropping in areca-nut

\begin{tabular}{|c|c|c|c|c|c|}
\hline Sr.No & Constraints & $\begin{array}{l}\text { Agreed } \\
\text { Farmers }\end{array}$ & $\begin{array}{l}\text { Neutral } \\
\text { Farmers }\end{array}$ & $\begin{array}{l}\text { Disagreed } \\
\text { Farmers }\end{array}$ & Rank \\
\hline \multirow[t]{6}{*}{ A } & \multicolumn{5}{|l|}{ Input constraint } \\
\hline & Non-availability of good quality inputs & $\begin{array}{c}150 \\
(48.38 \%)\end{array}$ & $\begin{array}{c}140 \\
(45.16 \%)\end{array}$ & $\begin{array}{c}20 \\
(6.45 \%)\end{array}$ & II \\
\hline & Unavailability of labour & $\begin{array}{c}90 \\
(29.03 \%)\end{array}$ & $\begin{array}{c}200 \\
(64.51 \%)\end{array}$ & $\begin{array}{c}20 \\
(6.45 \%)\end{array}$ & IV \\
\hline & Non-availability of good planting materials & $\begin{array}{c}110 \\
(35.48 \%)\end{array}$ & $\begin{array}{c}150 \\
(48.38 \%)\end{array}$ & $\begin{array}{c}50 \\
(16.12 \%)\end{array}$ & III \\
\hline & Shortage of water & $\begin{array}{c}80 \\
(25.80 \%)\end{array}$ & $\begin{array}{c}210 \\
(67.74 \%)\end{array}$ & $\begin{array}{c}20 \\
(6.45 \%)\end{array}$ & V \\
\hline & Non availability of inputs supplier & $\begin{array}{c}250 \\
(80.64 \%)\end{array}$ & $\begin{array}{c}50 \\
(16.12 \%)\end{array}$ & $\begin{array}{c}10 \\
(3.22 \%)\end{array}$ & I \\
\hline \multirow[t]{6}{*}{ B } & \multicolumn{4}{|l|}{ Technological constraints } & \\
\hline & Lack of knowledge on inter-cropping system & $\begin{array}{c}200 \\
(64.52 \%)\end{array}$ & $\begin{array}{c}100 \\
(32.26 \%)\end{array}$ & $\begin{array}{c}10 \\
(3.22 \%)\end{array}$ & IV \\
\hline & Lack of training infrastructure & $\begin{array}{c}250 \\
(80.65 \%)\end{array}$ & $\begin{array}{c}50 \\
(16.13 \%)\end{array}$ & $\begin{array}{c}10 \\
(3.22 \%)\end{array}$ & III \\
\hline & Lack of knowledge about pest and disease & $\begin{array}{c}270 \\
(87.10 \%)\end{array}$ & $\begin{array}{c}20 \\
(6.45 \%)\end{array}$ & $\begin{array}{c}20 \\
(6.45 \%)\end{array}$ & II \\
\hline & Lack of government support for inter-cropping system & $\begin{array}{c}300 \\
(96.78 \%)\end{array}$ & $\begin{array}{c}5 \\
(1.61 \%)\end{array}$ & $\begin{array}{c}5 \\
(1.61 \%)\end{array}$ & I \\
\hline & Lack of resistant varieties against pest and diseases & $\begin{array}{c}190 \\
(48.39 \%)\end{array}$ & $\begin{array}{c}80 \\
(25.81 \%)\end{array}$ & $\begin{array}{c}40 \\
(12.90 \%)\end{array}$ & V \\
\hline \multirow[t]{8}{*}{$\mathbf{C}$} & \multicolumn{4}{|l|}{ Economic constraints } & \\
\hline & Price fluctuation of farm produce & $\begin{array}{c}150 \\
(48.38 \%)\end{array}$ & $\begin{array}{c}110 \\
(35.49 \%)\end{array}$ & $\begin{array}{c}50 \\
(16.13 \%)\end{array}$ & V \\
\hline & Non availability of subsidies & $\begin{array}{c}300 \\
(96.78 \%)\end{array}$ & $\begin{array}{c}5 \\
(1.61 \%)\end{array}$ & $\begin{array}{c}5 \\
(1.61 \%)\end{array}$ & I \\
\hline & Increased cost of cultivation & $\begin{array}{c}5 \\
(1.61 \%)\end{array}$ & $\begin{array}{c}5 \\
(1.61 \%)\end{array}$ & $\begin{array}{c}300 \\
(96.77 \%)\end{array}$ & VII \\
\hline & Low yield & $\begin{array}{c}10 \\
(3.22 \%)\end{array}$ & $\begin{array}{c}80 \\
(25.80 \%)\end{array}$ & $\begin{array}{c}220 \\
(70.96 \%)\end{array}$ & VI \\
\hline & Exploitation by middle man & $\begin{array}{c}240 \\
(77.42 \%)\end{array}$ & $\begin{array}{c}60 \\
(19.36 \%)\end{array}$ & $\begin{array}{c}10 \\
(3.22 \%)\end{array}$ & IV \\
\hline & Did not get minimum price as compare top areca nut & $\begin{array}{c}250 \\
(80.65 \%)\end{array}$ & $\begin{array}{c}50 \\
(16.13 \%)\end{array}$ & $\begin{array}{c}10 \\
(3.22 \%)\end{array}$ & III \\
\hline & Unavailability of regular market & $\begin{array}{c}290 \\
(93.56 \%)\end{array}$ & $\begin{array}{c}10 \\
(3.22 \%)\end{array}$ & $\begin{array}{c}10 \\
(3.22 \%)\end{array}$ & II \\
\hline \multirow[t]{6}{*}{ D } & \multicolumn{4}{|l|}{ Biophysical constraints } & \\
\hline & Incidence of Pests and diseases & $\begin{array}{c}100 \\
(32.26 \%)\end{array}$ & $\begin{array}{c}200 \\
(64.52 \%)\end{array}$ & $\begin{array}{c}10 \\
(3.22 \%)\end{array}$ & III \\
\hline & Non availability space for planting intercrops & $\begin{array}{c}200 \\
(64.52 \%)\end{array}$ & $\begin{array}{c}50 \\
(16.13 \%)\end{array}$ & $\begin{array}{c}60 \\
(19.35 \%)\end{array}$ & I \\
\hline & Attack by domestic animals & $\begin{array}{c}50 \\
(16.13 \%)\end{array}$ & $\begin{array}{c}220 \\
(70.97 \%)\end{array}$ & $\begin{array}{c}40 \\
(12.90 \%)\end{array}$ & V \\
\hline & Poor quality of soil & $\begin{array}{c}150 \\
(48.38 \%)\end{array}$ & $\begin{array}{c}120 \\
(38.71 \%)\end{array}$ & $\begin{array}{c}40 \\
(12.91 \%)\end{array}$ & II \\
\hline & Due to high slope of the land & $\begin{array}{c}90 \\
(29.03 \%)\end{array}$ & $\begin{array}{c}210 \\
(67.75 \%)\end{array}$ & $\begin{array}{c}10 \\
(3.22 \%)\end{array}$ & IV \\
\hline \multirow[t]{4}{*}{$\mathbf{E}$} & \multicolumn{4}{|l|}{ Psychological constraints } & \\
\hline & Difficult for intercultural operations/harvesting & $\begin{array}{c}50 \\
(16.13 \%)\end{array}$ & $\begin{array}{c}70 \\
(22.58 \%)\end{array}$ & $\begin{array}{c}190 \\
(61.29 \%)\end{array}$ & I \\
\hline & Time consuming & $\begin{array}{c}10 \\
(3.22 \%)\end{array}$ & $\begin{array}{c}30 \\
(9.68 \%)\end{array}$ & $\begin{array}{c}270 \\
(87.10 \%)\end{array}$ & III \\
\hline & Reduction in yield of main crop by component crops & $\begin{array}{c}10 \\
(3.22 \%)\end{array}$ & $\begin{array}{c}120 \\
(38.71 \%)\end{array}$ & $\begin{array}{c}180 \\
(58.07 \%)\end{array}$ & II \\
\hline
\end{tabular}


The unavailability of space for plantation of crops is another major constraint faced by the farmers. The last but not the least, the major constraint face by the farmers is the difficulty for inter-culture operations and harvesting of the intercrops due to the lack of knowledge of the proper agriculture techniques. These results and findings are having similarities with the findings of Karmawati et al., (2019), Hong et al., (2019) and Bui et al., (2013).

It is therefore concluded that the socioeconomic characteristics of the adopters of inter-cropping were mostly of high level. The major constraints were the unavailability of supplier within the locality, lack of Government support, lack of subsidies, non availability of space and difficulty for intercultural operations/harvesting. If all these constraints are taking into proper considerations the farmers socio-economic status will increase tremendously. The government needs to provides proper training and carried out proper extension activities to help the farmers in developing their knowledge and skills and in persuading the non-adopters to practice the inter-cropping practices as a source of doubling the income of the farmers.

\section{References}

Bui Tan Yen, Saskia M. Visser, Chu Thai Hoanh, and Leo Stroosnijder (2013) Constraints in Agriculture production in Northern Upland uplands of Vietnam. Mountain Research and Development, 33(4): 404-415

Dai Xiaoqing, $\mathrm{Pu}$ Lijie and Rao Fangping, 2017.Assessing the Effect of a Crop-Tree Intercropping Program on Smallholders' Incomes in Rural Xinjiang, China. Sustainability, $\quad 9, \quad 1542$; doi:10.3390/su9091542.
HaneefRifat, Sharma Gyanendra and Ahmad Taufiq,2019.Constraints Faced by Farmers Practicing Organic Farming in Hill Region of Uttarakhand, India .International Journal of Current Microbiology and Applied Sciences ISSN: 2319-7706 Volume 8, Journal homepage: http://www.ijcmas.com

Jaganathan, D. and Nagaraja, N.R. 2015. Perception of Farmers about Areca nut Based Multi-species Cropping System .Indian Research. Journal of Extension.40(1): pp.50-55.

Karmawati E, Ardana I K, Siswanto and Soetopo, 2019. Factors effecting pepper production and quality in several production centre, $1 \mathrm{st}$ International Conference on Sustainable Plantation (1st ICSP 2019) IOP Conf. Series: Earth and Environmental Science, page 418 .

Kumaran, M., M. Sundaram, Shijo Mathew and P.R.Anand, 2018. Socio-personal contour, Information flow and Productivity of Brackish water aquaculture systems. An Appraisal Research Article Journal of Extension Education, Vol. 30, No. 3. DOI:https://doi.org/10.26725/JEE.2018.3.3 0.6119-6128.

Litsinger, J.A. and K. Moody. 1976. Integrated pest management of multiple cropping systems. p. 293-316 in R.I. Papendick, P.A. Sanchez, and G.B. Triplet (eds.). Multiple Cropping. Madison WI, American Society of Agronomy, Crop Science Society of America, and Soil Science Society of America, 378 p.

Yu Hong, Paul Berentsen, Nico Heerink,, Minjun Shi, Wopke van der Werf, 2019. The future of intercropping under growing resource scarcity and declining grain prices - A model analysis based on a case study in Northwest China. Agricultural Systems, 176, 102661.

\section{How to cite this article:}

Dasiewdorshisha Sancley and Syed H. Mazhar. 2020. Constraints Faced by the Respondents in Adopting Inter-Cropping Practices of Black Pepper and Betel Vine in Arecanut Plantation in Jirang Block of Ri-Bhoi District, Meghalaya, India. Int.J.Curr.Microbiol.App.Sci. 9(09): 174-178. doi: https://doi.org/10.20546/ijcmas.2020.909.021 